\title{
nesurating \\ Mobbing in the library workplace \\ What it is and how to prevent it
}

M

ost of us would like to associate the term mobbing in the library with crowds of people coming to use our collections and services. Unfortunately, there is a darker definition of mobbing: a type of workplace pathology in which employees target a co-worker and engage in an ongoing campaign of disrespectful, and even hostile, behavior. Typically, mobbing behaviors are covert and insidious; the mobbing victim is excluded from normal workplace activities and communications, with the ultimate goal of forcing the victim out of the organization. Mobbing is highly stressful because the targeted individual's social support system is undermined.

Managers may be tacit or active participants in the process. The perpetrated injustices are unfair but usually legal, and may fall within areas that are considered management prerogatives, such as eliminating an individual from meeting rosters, limiting access to resources or technical support, or altering job responsibilities. Often, mobbing victims are made to appear as though they are at fault, or are viewed as "crazy" or incompetent. When forced from the work group, their departure is depicted as their choice.

The concept of mobbing is not wellrecognized in the United States. In Englishspeaking countries, research has focused on the concept of bullying behavior between individuals, often when a person in a more powerful position is abusive toward a subordinate or less assertive person. Mobbing, with its overlay of group dynamics, is a more sophisticated and complex set of behaviors. Mobbing is clearly a form of harassment, but in the United States this term is connected with civil rights law, and denotes harmful behavior toward persons who have a protected status, such as race, religion, gender, or national origin.

One of the earliest researchers on the subject, Swedish psychologist Heinz Leymann, studied this type of workplace harassment and gave it the term mobbing-derived from observations in animal psychology of smaller animals ganging up on and overpowering a larger one. As a result of Leymann's and others' research, the concept of workplace mobbing is more well-known in Sweden and Germany. Much of Leymann's research has not been translated into English, as Thomas Hecker, a German studies librarian, notes in his article "Workplace Mobbing: A Discussion for Librarians." A concise source of information on mobbing in English is Noa Davenport's book Mobbing: Emotional Abuse in the Workplace. ${ }^{1}$ Kenneth Westhues, a Canadian researcher, has written several books about mobbing in academe. Much of the literature on mobbing focuses on case studies, which are fascinating reading but of relatively limited value since each workplace is unique and work group interactions are dynamic. Still, some behavior patterns emerge.

Research by Leymann and Kenneth Westhues shows that mobbing is more likely to occur in professional settings, where the work is complex, organizational goals may be am-

Reba Leiding is assistant to the dean at James Madison University Libraries and Educational Technologies, e-mail: leidinrm@jmu.edu

๑) 2010 Reba Leiding 
biguous, critical thinking is encouraged, and workers have relative autonomy. Academic libraries share some or all of these characteristics, and in fact libraries can be prime settings for workplace mobbing. Librarians often have a strong sense of service and loyalty to their library; they may gain positive rewards from working with their user communities and may be unwilling to risk these benefits by protesting against workplace abuse. Libraries as an institution are undergoing stresses from a more competitive information environment. In response, libraries may feel pressure to change their mission and values, revise their organizational structures, and add or eliminate services. The introduction of new technologies can alter workers' roles, provide a sense of depersonalization, and increase workloads. Organizational change prompted by stress can provide an opportunity for employment inequities, especially when lines of communication or authority are unclear. And, of course, economic constraints can limit the library resources and threaten job security, preventing employees from speaking out.

Leymann and Davenport outline these phases in the mobbing process:

- A triggering incident or conflict between the individual who comes to lead the mobbing attack, and the victim, and is unresolved.

- Continuing, sporadic, psychological assaults, or other forms of aggression, on the victim.

- Management involvement (if they are not already participating). Managers have the opportunity to rectify the situation, but if they are in denial or complicit in the process, at this stage they may act to further isolate or expel the victim.

- Expulsion from the organization. At this point, the employee, if he or she does not make a face- or career-saving move, may experience psychological or physical distress and post-traumatic stress-like symptoms, as well as a ruined career.

Leymann and others have focused on the psychological and physical symptoms of mobbing victims, which include anxiety, depression, and even suicide. Research has shown that co-workers who witness workplace mobbing but are not the direct victims can also exhibit symptoms of psychological distress.

Particular workplace dynamics contribute to a situation where mobbing can occur:

Dysfunctional organizations: Mobbing occurs in both hierarchical and flat organizations. The type of organizational structure in itself is not a factor; however, lack of communication, unclear lines of authority, ambiguous job descriptions, and laissez-faire management provide opportunities for mobbing behaviors. Organizations that tolerate mobbing are dysfunctional by definition, since workplace mobbing leads to worker turnover, declines in productivity, and costs from severance and early retirement payments. If mobbing is tolerated once, instigators see they can get away with aggressive behaviors, and mobbing becomes a part of the organization's culture. It is important to resolve the interpersonal conflict early in the process, to prevent the triggering event from becoming a justification for an aggression.

Active, involved management is crucial in controlling the mobbing dynamic. Many library managers have limited management training, and may not have awareness of the concept of mobbing or experience with resolving conflict. Managers are often promoted for their technical expertise, rather than their skill in handling interpersonal matters. Mackenzie and Smith, in their study of management education for library directors, found that most graduate library degree programs require only one management course, which may cover the gamut of management topics. ${ }^{2}$ Only seven management course syllabi in their study of 48 programs covered conflict, organization change, and development; further, only two syllabi covered ethics.

Mobbers: There are numerous reasons why an individual would instigate mobbing behavior, including psychological pathology, jealousy, greed, or desperation. The organization may provide a sense of scarce resources where employees feel they have to fight for perquisites and promotions. A 
weak, poorly managed organization may provide the aggressor with opportunities to target an individual. But why would normal, usually well-meaning people, join in with a mobbing instigator? One explanation is the element of groupthink: people want to feel a sense of group solidarity and inclusion. Poor communication lines or loose organizational structure may allow people to ignore aggressive incidents or deny that they have occurred. Lastly, fear can be a major factor: co-workers who witness the humiliating, demoralizing treatment the mobbing victim undergoes may feel that going along is the only way to avoid becoming a target as well.

The mobbing victim: Research has indicated that no single personality type is a typical mobbing target. Victims may be less assertive, or less inclined to be part of a group (and so more vulnerable to a group attack). They may have some characteristic that singles them out, such as a disability, or being the only man in a female-dominated group, or vice versa. Often, however, mobbing targets are strong contributors to the organization who are seen as principled, creative, and high achievers. Their status or accomplishments may make them targets. They may identify strongly with their organization, be committed to their profession, and find purpose and pleasure in their work. They may be reluctant to speak out about the aggressive behavior they experience because they do not want to harm their organization's reputation.

Prevention: Mobbing is less likely to gain a foothold in a workplace that has clear goals, well-defined job descriptions, and involved, unbiased management. Here are some steps to prevent mobbing in your library:

- Develop a clear mission statement that involves everyone in the organization.

- Adjust the mission and goals as needed to maintain flexibility, and institutionalize departmental changes and initiatives into the organizational structure, with clear lines of authority and communication. Base organizational structure on mission and goals, not on personalities.
- Provide training in ethics and "people skills," such as negotiation, conflict resolution, and workplace civility. Make these important values for all employees throughout the organization, and required skills for managers.

- Institute mentoring programs to foster knowledge transfer and professional support.

- Develop or improve internal communication channels so that all employees are aware of library activities and initiatives. This helps promote a sense of ownership in the organization.

The most important step an organization can take to prevent mobbing is to put in place mechanisms for resolving conflict. Provide and encourage opportunities for dealing with interpersonal problems as they occur. These may be as simple as a supervisor with an open-door policy or as formalized as official conflict resolution or grievance procedures. Mobbing is an opportunistic behavior, but it's not inevitable. Mobbing can be curtailed if workplaces support mechanisms that give targeted victims a chance to be heard, and more generally, foster an environment where fair and ethical behavior is viewed as the norm.

\section{Notes}

1. Thomas E. Hecker, "Workplace Mobbing: A Discussion for Librarians," Journal of Academic Librarianship 33, no. 4 (07, 2007): 439-45.

2. Maureen L. Mackenzie and James P. Smith, "Management Education for Library Directors: Are Graduate Library Programs Providing Future Library Directors with the Skills and Knowledge they Will Need?" Journal of Education for Library \& Information Science 50, no. 3 (Summer 2009): 129-42.

\section{Further reading}

Davenport, Noa, Ph.D, Ruth Distler Schwartz, and Gail Pursell Elliott. Mobbing: Emotional Abuse in the American Workplace. Ames, IA: Civil Society Publishing, 2002.

Gravois, John. "Mob Rule." Chronicle of Higher Education, 2006. 10.

Langan-Fox, Janice, Cary L. Cooper, and Richard J. Klimoski, eds. Research Com-

(continues on page 384) 
radio-program guides, publisher blurbs, magazine articles and other materials, Schmidt sent the items over a period of 30 years to his older sister, Lucy Kiesler, who lived in the United States. The collection's value for Schmidt scholarship and research lies in the potential for philological investigation into the nature of his work. The family history of the collection also may provide resource material for a future, comprehensive biography of Schmidt. The collection was donated to the Portland State Library by Lucy Kiesler's daughter-in-law.

\section{A collection of 100 artists' books by $\mathbf{7 9}$}

book artists has been received by the Oberlin

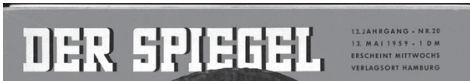

College Library. The collection was donated primarily by the individual artists in honor of Ruth Hughes, Oberlin Class of 1985 and chief cataloger at the Library Company of Philadelphia. An exhibition of the collection entitled "Show and Bestow: The Ruth Hughes Collection of Artists' Books" was on view at the Free Library of Philadelphia from November 20 to December 30, 2009 and at Oberlin from April 5 through June 10, 2010. An online exhibition of the collection as well as a PDF of the collection catalog are avail-

able from the collection web site at www. oberlin.edu/library/exhibits/ruth_hughes /ruthhughes.html. $\boldsymbol{n}$

("Open access...," continued from page 363)

7. For context, see program abstract and presentation for the 2004 Spring membership meeting of the Coalition for Networked Information: http://www.cni.org/tfms/2004a. spring/abstracts/PB-implications-fyffe.html.

8. "Final report of the faculty senate research committeee for FY-09," www2. ku.edu/ unigov/research09fr.pdf.

9. See for example faculty senate minutes for October 27, 2009 at http://www2. ku.edu/ unigov/fx102709min.shtml.

10. See Roger C. Schonfel and Ross Housewright "Faculty Survey 2009: Key Strategic Insights for Libraries, Publishers,

and Societies," Ithaka S+R, April 2010, http:// www.ithaka.org/ithaka-s-r/research/facultysurveys-2000-2009/Faculty\%20Study $\% 20$ 2009.pdf and also Diane Harley, and Sophia Krzys Acord, Sarah Earl-Novell, Shannon Lawrence, C. Judson King. "Assessing the Future Landscape of Scholarly Communication," University of California, Berkley. Center for Studies in Higher Education. January 2010, http://escholarship.org/uc/ item $/ 15 \times 7385 \mathrm{~g}$.

11. Press release on KU ScholarWorks at http://www.lib.ku.edu/news/ ku.scholarworks.ranking.shtml. $\boldsymbol{n}$

\section{("Mobbing in the library workplace," continued from page 366)}

panion to the Dysfunctional Workplace. Northampton, MA: Edward Elgar, 2007.

Pearson, Christine M., Lynne M. Andersson, and Christine L. Porath. "Assessing and Attacking Workplace Incivility." Organizational Dynamics 29, no. 2 (11, 2000): 123-37.
Westhues, Kenneth, ed. Winning, Losing, Moving on: How Professionals Deal With Workplace Harassment and Mobbing. Lewiston, NY: Edwin Mellen Press, 2005.

\section{. Workplace Mobbing in Academe:} Reports from Twenty Universities. Lewiston, NY: Edwin Melen Press, 2004. $n$ 